\title{
Front Matter: Volume 8746
}

, "Front Matter: Volume 8746," Proc. SPIE 8746, Algorithms for Synthetic Aperture Radar Imagery XX, 874601 (14 June 2013); doi:

$10.1117 / 12.2032359$

SPIE Event: SPIE Defense, Security, and Sensing, 2013, Baltimore, Maryland, SPIE. United States 


\section{PROCEEDINGS OF SPIE}

\section{Algorithms for Synthetic Aperture Radar Imagery XX}

Edmund Zelnio

Frederick D. Garber

Editors

1-2 May 2013

Baltimore, Maryland, United States

Sponsored and Published by

SPIE 
The papers included in this volume were part of the technical conference cited on the cover and title page. Papers were selected and subject to review by the editors and conference program committee. Some conference presentations may not be available for publication. The papers published in these proceedings reflect the work and thoughts of the authors and are published herein as submitted. The publisher is not responsible for the validity of the information or for any outcomes resulting from reliance thereon.

Please use the following format to cite material from this book:

Author(s), "Title of Paper," in Algorithms for Synthetic Aperture Radar Imagery XX, edited by Edmund Zelnio, Frederick D. Garber, Proceedings of SPIE Vol. 8746 (SPIE, Bellingham, WA, 2013) Article CID Number.

ISSN: 0277-786X

ISBN: 9780819495372

Published by

SPIE

P.O. Box 10, Bellingham, Washington 98227-0010 USA

Telephone +1 3606763290 (Pacific Time) Fax +1 3606471445

SPIE.org

Copyright (C) 2013, Society of Photo-Optical Instrumentation Engineers.

Copying of material in this book for internal or personal use, or for the internal or personal use of specific clients, beyond the fair use provisions granted by the U.S. Copyright Law is authorized by SPIE subject to payment of copying fees. The Transactional Reporting Service base fee for this volume is $\$ 18.00$ per article (or portion thereof), which should be paid directly to the Copyright Clearance Center (CCC), 222 Rosewood Drive, Danvers, MA 01923. Payment may also be made electronically through CCC Online at copyright.com. Other copying for republication, resale, advertising or promotion, or any form of systematic or multiple reproduction of any material in this book is prohibited except with permission in writing from the publisher. The CCC fee code is 0277-786X/13/\$18.00.

Printed in the United States of America.

Publication of record for individual papers is online in the SPIE Digital Library.

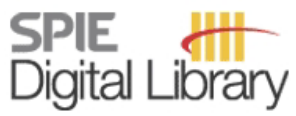

SPIEDigitalLibrary.org

Paper Numbering: Proceedings of SPIE follow an e-First publication model, with papers published first online and then in print and on CD-ROM. Papers are published as they are submitted and meet publication criteria. A unique, consistent, permanent citation identifier (CID) number is assigned to each article at the time of the first publication. Utilization of CIDs allows articles to be fully citable as soon as they are published online, and connects the same identifier to all online, print, and electronic versions of the publication. SPIE uses a six-digit CID article numbering system in which:

- The first four digits correspond to the SPIE volume number.

- The last two digits indicate publication order within the volume using a Base 36 numbering

system employing both numerals and letters. These two-number sets start with 00, 01, 02, 03, 04, $05,06,07,08,09,0 A, 0 B \ldots$. 0Z, followed by 10-1Z, 20-2Z, etc.

The CID Number appears on each page of the manuscript. The complete citation is used on the first page, and an abbreviated version on subsequent pages. Numbers in the index correspond to the last two digits of the six-digit CID Number. 


\section{Contents}

vii Conference Committee

\section{SESSION 1 IMAGE FORMATION}

874602 Frequency-dependent reflectivity image reconstruction [8746-1]

P. Sotirelis, J. Parker, X. Hu, Air Force Research Lab. (United States); M. Cheney, Colorado

State Univ. (United States); M. Ferrara, Matrix Research, Inc. (United States)

874603 Iteratively compensating for multiple scattering in SAR imaging [8746-2]

A. Martinez, Z. Qiao, The Univ. of Texas-Pan American (United States)

874604 Notched spectrum: from probing waveforms to receive filters [8746-3]

Y. Jiang, C. D. Gianelli, Integrated Adaptive Applications, Inc. (United States)

874605 Point source localization from de-ramped phase history bound on interferometric synthetic aperture radar (IFSAR) accuracy [8746-4]

M. Pepin, M. M. Hayat, The Univ. of New Mexico (United States)

874606 SAR focusing using multiple trihedrals [8746-5]

K. E. Dungan, J. W. Nehrbass, Dynamics Research Corp. (United States)

874607 An algorithm for upsampling spotlight SAR imagery: a Radarsat-2 SLC perspective [8746-6]

K. El-Darymli, C-CORE (Canada) and Memorial Univ. of Newfoundland (Canada);

P. McGuire, D. Power, C-CORE (Canada); C. Moloney, Memorial Univ. of Newfoundland

(Canada)

874608 An autofocus technique for video-SAR [8746-7]

R. Linnehan, J. Miller, E. Bishop, V. Horndt, General Atomics Aeronautical Systems Inc.

(United States)

874609 An application of backprojection for video SAR image formation exploiting a subaperature circular shift register [8746-8]

J. Miller, E. Bishop, A. Doerry, General Atomics Aeronautical Systems Inc. (United States)

8746 OA SAR digital spotlight implementation in MATLAB [8746-9]

K. E. Dungan, Dynamics Research Corp. (United States); L. A. Gorham, L. J. Moore, Air

Force Research Lab. (United States)

\section{SESSION 2 EXPLOITATION OF MOTION}

8746 OB Target migration path morphology of moving targets in spotlight SAR [8746-33]

D. A. Garren, J. W. Scrofani, M. Tummala, J. C. McEachen, Naval Postgraduate School (United States) 
8746 OD Augmenting synthetic aperture radar with space time adaptive processing [8746-11] M. Riedl, L. C. Potter, E. Ertin, The Ohio State Univ. (United States)

8746 OE Phase-wrapping ambiguity in along-track interferometry [8746-12]

R. Deming, Solid State Scientific Corp. (United States); R. llin, Air Force Research Lab. (United States); M. Best, Air Force Life Cycle Management Ctr. (United States)

8746 OF Adaptive resource allocation for synthetic aperture radars under resource constraints [8746-13]

G. E. Newstadt, Univ. of Michigan (United States); E. G. Zelnio, Air Force Research Lab. (United States); A. O. Hero III, Univ. of Michigan (United States)

8746 OG Multiple-object shape and motion reconstruction with missing radar data [8746-14] G. Arnold, M. Ferrara, Matrix Research, Inc. (United States); J. T. Parker, Air Force Research Lab. (United States)

$8746 \mathrm{OH} \quad$ SAR based classification of ground moving targets to assist vehicle tracking [8746-15] G. S. Goley, Etegent Technologies, Ltd. (United States); B. Rigling, Wright State Univ. (United States); A. R. Nolan, Etegent Technologies, Ltd. (United States)

\section{SESSION 3 AUTOMATIC TARGET DETECTION AND RECOGNITION}

8746 Ol Change detection experiments using Gotcha public release SAR data (Invited Paper) [8746-16] I. Stojanovic, L. Novak, Scientific Systems Co., Inc. (United States)

8746 OJ Joint imaging and change detection for robust exploitation in interrupted SAR environments [8746-17]

J. N. Ash, The Ohio State Univ. (United States)

8746 OK Spatially variant incoherence trimming for improved SAR CCD [8746-18]

D. B. André, D. Blacknell, Defence Science and Technology Lab. (United Kingdom);

K. Morrison, Cranfield Univ. (United Kingdom)

$8746 \mathrm{OL}$ Joint reconstruction of interrupted SAR imagery for persistent surveillance change detection [8746-19]

I. Stojanovic, L. Novak, Scientific Systems Co., Inc. (United States); W. C. Karl, Boston Univ. (United States)

8746 ON Focusing, imaging, and ATR for the Gotcha 2008 wide angle SAR collection [8746-21]

C. D. Gianelli, L. Xu, Integrated Adaptive Applications, Inc. (United States)

\section{SESSION 4 SENSOR MANAGEMENT}

$8746 \mathrm{OP} \quad$ Value-of-information aware active task assignment [8746-23]

B. Mu, G. Chowdhary, J. P. How, Massachusetts Institute of Technology (United States) 
8746 OT Geometic image formation for target identification in multi-energy computed tomography [8746-27]

B. H. Tracey, E. L. Miller, Tufts Univ. (United States)

8746 OU Spatiotemporal Gaussian feature detection in sparsely sampled data with application to InSAR [8746-28]

A. Vaccari, S. T. Acton, Univ. of Virginia (United States)

8746 OV Detection in networked radar [8746-29]

K. Beaudet, L. Crider, D. Cochran, Arizona State Univ. (United States)

Author Index 
Proc. of SPIE Vol. $8746874601-6$

Downloaded From: https://www.spiedigitallibrary.org/conference-proceedings-of-spie on 26 Apr 2023 Terms of Use: https://www.spiedigitallibrary.org/terms-of-use 


\title{
Conference Committee
}

\author{
Symposium Chair
}

Kenneth R. Israel, Major General (USAF Retired) (United States)

Symposium Cochair

David A. Whelan, Boeing Defense, Space, and Security (United States)

Conference Chairs

Edmund Zelnio, Air Force Research Laboratory (United States)

Frederick D. Garber, Wright State University (United States)

Conference Program Committee

David Blacknell, Defence Science and Technology Laboratory (United Kingdom)

Mujdat Cetin, Sabanci University (Turkey)

Gil J. Ettinger, Systems \& Technology Research (United States)

Charles V. Jakowatz Jr., Sandia National Laboratories (United States)

Eric R. Keydel, SAIC (United States)

Juan Li, University of Central Florida (United States)

Michael J. Minardi, Air Force Research Laboratory (United States)

Randolph L. Moses, The Ohio State University (United States)

Les Novak, Scientific Systems Company, Inc. (United States)

Lee C. Potter, The Ohio State University (United States)

Brian Rigling, Wright State University (United States)

Timothy D. Ross, Jacobs Technology (United States)

Michael A. Saville, Air Force Research Laboratory (United States)

Gerard W. Titi, BAE Systems (United States)

\section{Session Chairs}

1 Image Formation

Joshua N. Ash, The Ohio State University (United States)

2 Exploitation of Motion

Joshua N. Ash, The Ohio State University (United States) 
3 Automatic Target Detection and Recognition

David Blacknell, Defence Science and Technology Laboratory (United Kingdom)

4 Sensor Management

Alfred O. Hero III, University of Michigan (United States) 